\title{
Treatment outcome and prognostic indices in patients with hyperglycemic emergencies
}

This article was published in the following Dove Press journal:

Diabetes, Metabolic Syndrome and Obesity: Targets and Therapy

17 August 2013

Number of times this article has been viewed

\section{IU Ezeani ${ }^{1}$}

\section{A Eregie ${ }^{2}$ OS Ogedengbe ${ }^{2}$}

'Department of Medicine, Federal Medical Centre, Umuahia, Abia State, Nigeria; ${ }^{2}$ Department of Medicine, University of Benin Teaching Hospital, Benin City, Nigeria
Correspondence: IU Ezeani

Department of Medicine, Federal Medical Center, P.M.B 700I, Umuahia,

Abia State, 440, Nigeria

Tel +2348060692131

Email ignatiusez@yahoo.com
Objective: The objective of this study is to assess the treatment outcomes in patients with hyperglycemic emergencies and to ascertain the factors associated with outcome, with emphasis on the determinants of outcome.

Method: A total of 105 patients admitted to the Accident and Emergency unit, who fulfilled the criteria for hyperglycemic emergencies, were selected. The information extracted included sociodemographic, clinical, and laboratory data, as well as hospitalization outcome.

Results: Of the 105 subjects that participated in the study, hyperosmolar hyperglycemic nonketotic state (HHNK) was seen in 50\% (53) of the subjects, while diabetic ketoacidosis (DKA) was seen in 31\% (29), normo-osmolar nonketotic hyperglycemic state (NNHS) in 12\% (13), and mixed hyperglycemic emergency in 7\% (10) of the subjects. The overall mortality rate in this study was $4.8 \%$. Three deaths were recorded in patients with HHNK, while DKA and NNHS each had one death. Three of the deaths occurred within the first 24 hours of admission while the other two were more than 24 hours after admission. The mean (standard deviation) total duration of hospital stay was 24.2 days (SD), and the range of stay was $0.5-88$ days.

Conclusion: The most common type of hyperglycemic emergency seen in this study was HHNK. Also, the presence of infection, and sex of the study subject, were significant determinants of outcome in this study.

Keywords: hyperglycemia, emergency, diabetes mellitus, insulin

\section{Introduction}

The complications of diabetes mellitus (DM) could be acute or chronic. ${ }^{1}$ Acute complications of DM include diabetic ketoacidosis (DKA), hyperglycemic hyperosmolar nonketotic state (HHNK), lactic acidosis, and normo-osmolar nonketotic hyperglycemic state (NNHS); of these, DKA and HHNK are the two most common hyperglycemic emergencies. ${ }^{1}$

HHNK was first described by Sament and Schwartz ${ }^{2}$ in 1957 . NNHS is seen in a subset of patients who present with hyperglycemia, insignificant ketonuria, and normal osmolality with symptoms of metabolic decompensation. ${ }^{3,4}$ These groups of patients do not fit into the criteria for DKA or HHNK.

Hyperglycemic emergencies are often encountered as DM-complications in clinical practice. They are the most serious acute metabolic complications of DM and are associated with excess mortality. ${ }^{5}$ In Spain, a study conducted by Piniés et al, ${ }^{6}$ which aimed to determine the course and outcome of 132 patients with HHNK, showed a mortality rate of $16.9 \%$. Another study by Kitabchi and Nyenwe ${ }^{7}$ in the US showed a declining mortality rate in patients with DKA compared with HHNK, which remained 
alarmingly high. In Nigeria, hyperglycemic emergencies are an important cause of morbidity and mortality due to poor drug compliance, and this may be attributed to poverty, ignorance, poor health education, infection, delayed diagnosis and treatment, lack of access to medical care, erratic supply of essential drugs, cultural and religious beliefs, poor laboratory support, and less emphasis on electrolyte monitoring, especially potassium..$^{8-11}$

A study done by Osuntokun et $\mathrm{al}^{12}$ in 1971 in Ibadan reported DKA as the single major cause of death in diabetics. Necropsy studies carried out 5 years later in Ibadan by Smith and Adetuyibi ${ }^{13}$ showed that $43 \%$ of deaths in acute decompensated diabetics were due to DKA. A report from Port-Harcourt by Dagogo-Jack ${ }^{14}$ in 1991 showed a mortality rate of $22 \%$. Three years later, Ndububa and Erhabor ${ }^{10}$ from Ilesha reported a mortality rate of $22 \%$. A mortality rate of $60 \%$ for $\mathrm{HHNK}$ was reported from Ile-Ife in 2000 by Kolawole and Ajayi. ${ }^{15}$ In the same year, Talabi reported a mortality rate of $50 \%$ for HHNK in Ibadan.

\section{Method}

This study was carried out at the Accident and Emergency unit and the Medical wards of the University of Benin Teaching Hospital (UBTH), Benin City, Nigeria. Subjects recruited for this study were patients admitted at the Accident and Emergency unit of UBTH on account of a hyperglycemic emergency (HE). Based on a calculated minimum sample size of 102, 105 patients were recruited. The study was a prospective longitudinal study. Patients admitted to the Emergency unit who fulfilled the criteria for hyperglycemic emergencies were selected using a nonprobability sampling technique. The information that was extracted included sociodemographic, clinical, and laboratory data. Subjects were recruited if they met the following criteria: random plasma glucose $(\mathrm{RBS})>17 \mathrm{mmol} / \mathrm{L}(300 \mathrm{mg} / \mathrm{dL})$, ketonuria of $2+$ or more, and serum bicarbonate of less than $18 \mathrm{mmol} / \mathrm{L}$ for DKA; ${ }^{16,17} \mathrm{RBS}>25 \mathrm{mmol} / \mathrm{L}(450 \mathrm{mg} / \mathrm{dL})$ and plasma osmolality $>320 \mathrm{mOsmol} / \mathrm{L}$ with insignificant ketonuria for HHNK; ${ }^{16,18}$ RBS > 17 mmol/L (300 mg/dL), serum osmolality $<320 \mathrm{mOsmol} / \mathrm{L}$, and absent or minimal (1+) ketonuria for NNHS; ${ }^{16,18}$ RBS level $>300 \mathrm{mg} / \mathrm{dL}$, serum bicarbonate level $<15 \mathrm{mmol} / \mathrm{L}$, and ketonuria of $2+$ or more for mixed DKA and HHNK; ${ }^{19,20}$ the patient gave consent (verbally obtained from them in the language best understood by the patient/relatives); and the patient was aged above 18 years. The exclusion criteria included: patients diagnosed with end stage renal disease (ESRD), congestive cardiac failure (CCF), hepatic failure and anasarca due to their fluid overload as these conditions affect rapid intravenous fluid administration; patients with dementia in which there is alteration of mental state and likely an inability to complain of hyperglycemic symptoms; and pregnant women due to the gravid state. Ethical approval was obtained from the Ethics and Research committee of UBTH before the commencement of the study.

\section{Treatment}

Once the diagnosis was confirmed, therapy was commenced using the local protocol for management of hyperglycemic emergencies.

\section{Results}

\section{Sociodemographic characteristics}

Of the 105 subjects who completed the study, 53 (51\%) were male while 52 (49\%) were female. Ninety-one subjects (86.7\%) had type $2 \mathrm{DM}$ and 14 (13.3\%) had type $1 \mathrm{DM}$. Twenty-eight (27\%) patients had DM for more than or equal to 10 years duration, while 77 (73\%) of the patients had DM for less than 10 years duration.

\section{Pattern of hyperglycemic emergencies}

Four major diabetic HE types were seen at the emergency unit: HHNK, DKA, mixed DKA/HHNK, and NNHS. The most common HE was HHNK, accounting for 50\% (53) of the subjects, while DKA was seen in $31 \%$ (29), NNHS in $12 \%$ (13), and mixed HE accounted for 7\% (10) of the subjects.

The duration of stay in the ward and the total duration of hospital stay were highest in patients with mixed DKA/ HHNK followed by patients with DKA, patients with NNHS, and patients with HHNK, in descending order (Table 1).

The highest mortality rate was recorded in the HHNK group of HE (total of three deaths), while DKA and NNHS had one mortality each (Table 2).

Table 3 shows a higher mortality rate among male (80\%) as compared to female subjects $(20 \%)$. Also all instances of mortality recorded were in subjects with some level of education.

Table 4 shows that the most common precipitating factor in this study was infection (in 57\% of study subjects). Other notable precipitating factors include newly diagnosed DM and nonadherence to medications.

\section{Outcome and discussion}

\section{General outcome}

The higher morbidity and mortality rates that occur in patients with $\mathrm{HE}$ in developing countries are as a result of paucity of 
Table I Comparison of duration of hospital stay according to the various hyperglycemic emergencies

\begin{tabular}{lcccccr}
\hline Parameter & $\begin{array}{l}\text { DKA } \\
\mathbf{n}=\mathbf{2 9} \\
\text { Mean } \pm \text { SD }\end{array}$ & $\begin{array}{l}\text { HHNK } \\
\mathbf{n}=\mathbf{5 3} \\
\text { Mean } \pm \text { SD }\end{array}$ & $\begin{array}{l}\text { NNHS } \\
\mathbf{n}=\mathbf{I 3} \\
\text { Mean } \pm \text { SD }\end{array}$ & $\begin{array}{l}\text { Mixed } \\
\mathbf{n}=1 \mathbf{0} \\
\text { Mean } \pm \text { SD }\end{array}$ & ff & P \\
\hline $\begin{array}{l}\text { Duration of stay } \\
\text { at A\&E (days) }\end{array}$ & $1.6 \pm 1.13$ & $1.2 \pm 2.17$ & $1.4 \pm 1.19$ & $1.0 \pm 2.24$ & 5.38 & 3 \\
$\begin{array}{l}\text { Duration of stay } \\
\text { on the ward (days) }\end{array}$ & $26.9 \pm 15.25$ & $19.2 \pm 12.44$ & $23.0 \pm 20.52$ & $30.8 \pm 21.10$ & 2.28 & 3 \\
$\begin{array}{l}\text { Total duration } \\
\text { on admission (days) }\end{array}$ & $28.6 \pm 17.65$ & $20.4 \pm 13.65$ & $24.4 \pm 21.30$ & $32.8 \pm 21.30$ & 2.45 & 3 \\
\hline
\end{tabular}

Abbreviations: A\&E, accident and emergency; DKA, diabetic ketoacidosis; HHNK, hyperosmolar hyperglycemic nonketotic state; Mixed, mixed diabetic ketoacidosis/ hyperosmolar hyperglycemic nonketotic state; NNHS, Normo-osmolar nonketotic hyperglycemic state; SD, standard deviation.

medical facilities and personnel, late hospital presentation, and prevalent socioeconomic distress. ${ }^{21,22}$ However, morbidity and mortality still occur in developed countries, albeit at a much lower rate. The overall mortality rate in this study was $4.8 \%$, which is lower than the rates of $18.8 \%$ and $16 \%$ reported by Ehusani ${ }^{3}$ and Adesina, ${ }^{23}$ respectively. Comparing mortality rates for diabetic emergencies is difficult as the definition of presenting syndromes varies and it is based on arbitrary clinical and biochemical criteria. ${ }^{24}$ Most reported mortality rates are not adjusted for age effects and many studies investigating mortality rates for DKA have grouped all acidotic presentations together, regardless of the degree of hyperosmolarity. ${ }^{24}$ Given the above limitations, it is of note that MacIsaac et al ${ }^{24}$ reported a similar mortality rate of $4.8 \%$. It is also lower than the $22 \%$ and $25 \%$ for DKA and HHNK, respectively, reported by Okoro et $\mathrm{al}^{25}$ in Ilorin and the $18 \%$ reported by Ogbera et al. ${ }^{5}$ Eregie and Unadike ${ }^{26}$ reported a mortality rate of $27.7 \%$ among DKA patients in Benin. In South Africa, Zouvanis et $\mathrm{al}^{27}$ reported that mortality rate from DKA among the black Africans in Johannesburg is low and comparable to the mortality rate in Western Europe. The lower mortality rate in this study could be attributed to the fact that subjects received close monitoring due to the

Table 2 Comparison of outcome of hyperglycemic emergencies seen in UBTH

\begin{tabular}{llllllll}
\hline Parameter & $\begin{array}{l}\text { DKA } \\
\mathbf{n}=\mathbf{2 9}\end{array}$ & $\begin{array}{l}\text { HHNK } \\
\mathbf{n}=\mathbf{5 3}\end{array}$ & $\begin{array}{l}\text { NNHS } \\
\mathbf{n}=\mathbf{1 3}\end{array}$ & $\begin{array}{l}\text { Mixed } \\
\mathbf{n}=10\end{array}$ & $X^{2}$ & df & $\mathbf{P}$ \\
\hline $\begin{array}{l}\text { Discharged } \\
\text { home }\end{array}$ & 28 & 50 & 12 & 10 & 1.34 & 6 & 0.97 \\
$\begin{array}{l}\text { Death within } \\
24 \text { hours }\end{array}$ & $\mathrm{I}$ & $\mathrm{I}$ & $\mathrm{I}$ & 0 & & & \\
$\begin{array}{l}\text { Death after } \\
24 \text { hours }\end{array}$ & 0 & 2 & 0 & 0 & & & \\
\hline
\end{tabular}

Abbreviations: DKA, diabetic ketoacidosis; HHNK, hyperosmolar hyperglycemic nonketotic state; Mixed, mixed diabetic ketoacidosis/hyperosmolar hyperglycemic nonketotic state; NNHS, Normo-osmolar nonketotic hyperglycemic state; UBTH, University of Benin Teaching Hospital; df, degrees of freedom. relatively high number of medical personnel deployed in the management of these patients.

Three deaths were recorded in patients with HHNK, while DKA and mixed HHNK/DKA had one death each, with all the deaths attributed to precipitating factors of HE and the resultant complications. Three of the deaths were within the first 24 hours of admission, while the other two were more than 24 hours after admission. Two of the five deaths were as a result of sepsis from diabetic foot ulcers. Two other mortalities were from patients with nonadherence to drugs, and these patients also suffered from cerebrovascular accidents.

\section{Duration of hospital stay}

The mean (standard deviation [SD]) total duration of hospital stay was 24.2 (17.1) days and the range of stay was $0.5-88$ days. This finding was similar to the finding from the study by Ogbera et al, ${ }^{5}$ who reported a mean (SD) duration of 23 (17) days with a range of 4-122 days. Subjects with

Table 3 Influence of demographic parameters on outcome

\begin{tabular}{|c|c|c|c|c|c|}
\hline Parameter & $\begin{array}{l}\text { Discharged home } \\
n=100\end{array}$ & $\begin{array}{l}\text { Died } \\
n=5\end{array}$ & $X^{2}$ & $d f$ & $P$ \\
\hline \multicolumn{6}{|l|}{ Age group (years) } \\
\hline $20-29$ & 8 & 1 & 0.93 & 6 & 0.99 \\
\hline $30-39$ & II & I & & & \\
\hline $40-49$ & II & 1 & & & \\
\hline $50-59$ & 28 & 0 & & & \\
\hline $60-69$ & 26 & I & & & \\
\hline $70-79$ & II & I & & & \\
\hline $80-89$ & 5 & 0 & & & \\
\hline \multicolumn{6}{|l|}{ Sex } \\
\hline Male & 49 & 4 & 0.80 & 1 & 0.37 \\
\hline Female & 51 & 1 & & & \\
\hline \multicolumn{6}{|l|}{ Level of education } \\
\hline No education & 8 & 0 & 1.19 & 3 & 0.76 \\
\hline Primary & 28 & 0 & & & \\
\hline Secondary & 34 & 2 & & & \\
\hline Tertiary & 30 & 3 & & & \\
\hline
\end{tabular}

Abbreviation: $d f$, degrees of freedom. 
Table 4 Association between precipitating factors of hyperglycemic emergencies and outcome

\begin{tabular}{|c|c|c|c|c|c|c|}
\hline Factors & $\begin{array}{l}\text { Discharged home } \\
n=100\end{array}$ & $\begin{array}{l}\text { Death within } 24 \text { hours } \\
n=2\end{array}$ & $\begin{array}{l}\text { Death after } 24 \text { hours } \\
n=3\end{array}$ & $x^{2}$ & $d f$ & $P$-value \\
\hline Infection & 57 (57\%) & I (50\%) & I (33.3\%) & 9.32 & 12 & 0.68 \\
\hline CVA & II (II\%) & 0 & 0 & & & \\
\hline Fracture & I (I\%) & 0 & 0 & & & \\
\hline Newly diagnosed & 15 (I5\%) & 0 & 0 & & & \\
\hline Non adherence & $13(13 \%)$ & I (50\%) & $2(66.7 \%)$ & & & \\
\hline RTA & $3(3 \%)$ & 0 & 0 & & & \\
\hline
\end{tabular}

Abbreviations: CVA, cerebrovascular accident; RTA, road traffic accident; $d f$, degrees of freedom.

diabetic foot ulcers (DFU) had the longest hospital duration of stay, which is similar to findings from studies by Ehusani, ${ }^{3}$ Adesina, ${ }^{23}$ and Pepper et al, ${ }^{28}$ who noted that DFU are usually associated with a much longer duration of hospital stay. The reason for the long duration of hospital stay is the presentation with advanced stages of foot ulcer, which usually require a longer time for wound closure and healing with elaborate and multidisciplinary care. Subjects with HHNK had the shortest mean (SD) total duration of stay of 20.4 (13.6) days, while mixed DKA/HHNK had the longest mean (SD) total duration of stay of 32.8 (21.2) days. The comorbidities with which subjects presented may have accounted for this difference.

Furthermore, two of the mortalities had a secondary level of education, while the other three had tertiary education. Although literature highlighting the influence of education on outcome is insufficient, Nyenwe et $\mathrm{al}^{29}$ in Port Harcourt reported that people in the highest social class had a higher prevalence of DM than those in the lower social classes. Zimmet $^{30}$ also noted that diabetes was more common in upper class families in the developing countries of the world, although a noncommunicable disease survey in Nigeria reported a crude prevalence of $4.6 \%$ in the lowest social class compared to $2.5 \%$ in the highest social class. ${ }^{29}$ Explanations for the discrepancy documented in this national survey are unclear. A further extensive national survey will be required to see if this pattern is maintained and to deduce the possible reasons for this.

\section{Influence of demographic parameters on outcome}

Four out of the five persons who died (80\%) in this study were male. The mortality rate in males was $8 \%$ compared to females who had a mortality rate of $2 \%$; this is similar to the finding from the study done by Kolawole and Ajayi, ${ }^{15}$ who reported that the outcome is worse in admitted male diabetic patients. Ogbera et $\mathrm{al}^{5}$ also noted that being male is predictive of a fatal diabetic outcome. In his study, Adesina ${ }^{23}$ also reported a mortality rate of $28 \%$ in males compared to a mortality rate of $4 \%$ in female subjects. The reasons for the increased mortality in admitted male diabetic patients is unclear, but is probably related to the existing comorbidities/ pattern of presentation.

There were two instances of mortality in young patients and two in elderly patients, while the other mortality was a middle-aged man. There was no statistically significant difference between age and outcome in this study. This is slightly different from findings from a similar study, which has shown that age is a poor prognostic factor. ${ }^{24}$ The reason that may be attributed to this is that out of the three non-elderly deaths recorded in this study, two of them had intracerebral hemorrhage, while one young subject went into hypoglycemic coma, which may have contributed to their death.

\section{Prognostic factors in hyperglycemic emergencies}

Of note in this study is the fact that two of the subjects who died had DFU characterized by ascending gangrene resulting in overwhelming sepsis. A previous study had also reported fatal outcomes in patients with DFU. ${ }^{5}$ Reasons that may be attributed to this include late presentation to the hospital, erroneous traditional beliefs, and high treatment costs. ${ }^{5}$

All the mortalities recorded were in subjects who had DM duration of less than 10 years prior to presentation. This is in keeping with findings from the study done by Ogbera et $\mathrm{al}^{5}$ who reported that 18 of the 23 subjects who died (78.2\%) in their study had a shorter duration of DM prior to presentation with hyperglycemic emergency. This may be due to ignorance of DM complications and the need for early presentation to the hospital when complications arise. Adequate health education covering all relevant aspects of DM care will reduce this pattern.

\section{Conclusion}

The highest number of mortalities was recorded in patients with HHNK, and clinical profiles of these patients at presentation have a prognostic index on the outcome. It is also evident from this study that patients with HHNK require 
more insulin than patients with other HE, although they were found to have a shorter duration of stay while on admission in the ward. Furthermore, hypertension was the most common comorbidity in this study; this further highlights the need for physicians attending to these patients to have a high index of suspicion in order to recognize patients with hypertension and commence early treatment. Also, infections should be treated urgently with appropriate antibiotics in diabetic patients as this has been identified as the most common precipitating factor of HE, with the attendant morbidity and mortality. This study also revealed that mortality was higher in male patients and patients have had diabetes for 10 years or more.

\section{Disclosure}

The authors report no conflicts of interest in this work.

\section{References}

1. Alvin CP. Diabetes Mellitus. Aetiological classification. In: Kasper DL, Braunwald E, Fauci AS, Hauser SL, Longo DL, Jameson JL, editors. Harrison's Principles of Internal Medicine, 16th ed. New York: McGraw Hill; 2005;323:2158-2161.

2. Sament S, Schwartz MB. Severe diabetic stupor without ketosis. S Afr Med J. 1957;31:893-894.

3. Ehusani FO. Comparative Study of Intravenous Insulin Infusion and Intermittent Intramuscular Injection of Insulin in the Management of Hyperglycaemic Emergencies [dissertation]. Lagos: National Postgraduate Medical College; 2000.

4. Rolfe M, Ephraim GG, Lincoln DC, Huddle KR. Hyperosmolar nonketotic diabetic coma as a cause of emergency hyperglycaemic admission to Baragwaneth Hospital. S Afr Med J. 1995;85(3):173-176.

5. Ogbera AO, Awobusuyi J, Unachukwu C, Fasanmade O. Clinical features, predictive factors and outcome of hyperglycaemic emergencies in a developing country. BMC Endocr Disord. 2009;9:9.

6. Piniés JA, Cairo G, Gaztambide S, Vazquez JA. Course and prognosis of 132 patients with diabetic non-ketotic hyperosmolar state. Diabete Metab. 1994;20:43-48.

7. Kitabchi AE, Nyenwe EA. Hyperglycemic crises in diabetes mellitus: diabetic ketoacidosis and hyperglycemic hyperosmolar state. Endocrinol Metab Clin North Am. 2006;35(4):725-751.

8. Anumah FO. Management of hyperglycaemic emergencies in the tropics. Ann Afr Med. 2007;6:45-50.

9. PIOpara, ICAnochie, F U Eke. Childhood diabetes mellitus in Port Harcourt: any change in prevalence and outcome. PHMJ. 2008;2(2):126-129.

10. Ndububa DA, Erhabor GE. Diabetes mortalities in Ilesha, Nigeria: a retrospective study. Cent Afr J Med. 1994;40:286-289.

11. Amata AO. Problems and challenges of managing ketoacidosis in tropical developing countries. International Diabetes Digest. 1994;105:18-21.

12. Osuntokun BO, Akinkugbe FM, Francis TI, Reddy S, Osuntokun O, Taylor GO. Diabetes mellitus in Nigerians: a study of 832 patients. West Afr Med J Niger Pract. 1971;20:295-312.
13. Smith JA, Adetuyibi A. Diabetes in the Nigerian African. II. Autopsy studies. Trop Geogr Med. 1976;28:159-164.

14. Dagogo-Jack S. Survey of diabetes and patient mortality in Port Harcourt, Nigeria. Orient J Medicine. 1991;3(1):37-41. Available from: http://pubs.sciepub.com/ajmsm/1/3/1/abstract.html\#.UfFN_Bs1ibE. Accessed July 10, 2013.

15. Kolawole BA, Ajayi AA. Prognostic indices for intra-hospital mortality in Nigerian diabetic NIDDM patients. Role of gender and hypertension. J Diabetes Complications. 2000;14(2):84-89.

16. Brownlee M, Aiello LP, Cooper ME, Vinik AI, Nesto RW, Boulton AJM. Complications of diabetes mellitus. In: Kronenberg HM, Melmed S, Polonsky KS, Larsen PR, editors. Williams Textbook of Endocrinology, 11th ed. Philadelphia: Saunders; 2008;30:1329-1416.

17. Rheeder P. Type 2 diabetes: the emerging epidemic. S Afr Fam Pract. 2006;48(10):20.

18. Söderberg S, Zimmet P, Tuomilehto J, et al. Increasing prevalence of Type 2 diabetes mellitus in all ethnic groups in Mauritius. Diabet Med. 2005;22(1):61-68.

19. Wild S, Roglic G, Green A, Sicree R, King H. Global prevalence of diabetes: estimates for the year 2000 and projections for 2030. Diabetes Care. 2004;27(5):1047-1053.

20. Motala AA. Diabetes trends in Africa. Diabetes Metab Res Rev. 2002;18 Suppl 3:S14-S20.

21. Fabiyi AK, Kolawole BA, Adefehinti O, Ikem RT. The impact of Knowledge, attitude, practice and beliefs of type 2 Nigerian diabetic patients on drug compliance. Diabetes International. 2002;12:15-17. Available from: http://link.springer.com/article/10.1023/ B:QURE.0000037483.85545.5f. Accessed July 10, 2013.

22. Haile S. Management of diabetic ketoacidosis with lente insulin. Diabetes International. 2000;10:61.

23. Adesina OF. Comparison of Lispro Insulin and Regular Insulin in the Management of Hyperglycemic Emergencies [dissertation]. Lagos: National postgraduate Medical College; 2008.

24. MacIsaac RJ, Lee LY, McNeil KJ, Tsalamandris C, Jerums G. Influence of age on the presentation and outcome of acidotic and hyperosmolar diabetic emergencies. Intern Med J. 2002;32(8):379-385.

25. Okoro EO, Yusuf M, Salawu HO, Oyejola BA. Outcome of diabetic hyperglycaemic emergencies in a Nigerian cohort. Chinese Journal of Medicine. 2007;2(2):77-82.

26. Eregie A, Unadike BC. Common causes of morbidity and mortality amongst diabetic admissions at the University of Benin Teaching Hospital, Benin City, Nigeria. Pak J Med Res. 2010;49(3):89-93.

27. Zouvanis M, Pieterse AC, Seftel HC, Joffe BI. Clinical characteristics and outcome of hyperglycaemic emergencies in Johannesburg Africans. Diabet Med. 2004;14(7):603-606.

28. Pepper DJ, Levitt NS, Cleary S, Burch VC. Hyperglycaemic emergencies admissions to a secondary-level hospital: an unnecessary financial burden. S Afr Med J. 2007;97(10):963-967.

29. Nyenwe EA, Odia OJ, Ihekwaba AE, Ojule A, Babatunde S. Type 2 diabetes in adult Nigerians: a study of its prevalence and risk factors in Port Harcourt, Nigeria. Diabetes Res Clin Pract. 2003;62(3): 177-185.

30. Zimmet P. Type 2 (non-insulin-dependent) diabetes - an epidemiological overview. Diabetelogia. 1982;22(6):399-411.

Diabetes, Metabolic Syndrome and Obesity: Targets and Therapy

\section{Publish your work in this journal}

Diabetes, Metabolic Syndrome and Obesity: Targets and Therapy is an international, peer-reviewed open-access journal committed to the rapid publication of the latest laboratory and clinical findings in the fields of diabetes, metabolic syndrome and obesity research. Original research, review, case reports, hypothesis formation, expert opinion and commentaries are all considered for publication. The manuscript management system is completely online and includes a very quick and fair peer-review system, which is all easy to use. Visit http://www.dovepress.com/testimonials.php to read real quotes from published authors. 